\title{
Elements of a Powerful Partnership
}

\author{
by Carol A. Brown
}

$T$

he primary purpose of the Library Services and Technology Act (LSTA) is to promote the use of technology for the sharing of information between libraries and community agencies. To achieve this goal, LSTA funds are made available to state library agencies, with subgrants to public, academic, research, school, and special libraries within each state. Secondary goals are to provide extended library services and increased access to information for children and youth within their communities. ${ }^{1}$ The Powerful Partners Collaboration Grant is a collaborative effort using LSTA funds for educational outreach and increased visibility for libraries in the community. Powerful Partners are perfect examples of successful partnerships between libraries and communities for reaching children and youth. ${ }^{2}$

Between the years 1997 and 1999, the State Library of North Carolina participated in a study to determine how well the leaders in libraries across the state were meeting the vision for providing children and youth opportunities to "learn to read, love to learn, and have access to the world," one statement of several other goals included in Evaluation of the Library Services and Technology Act Plan for Implementation. ${ }^{3}$ Surveys and focus groups were used to gather information from both public and school libraries. Based on these findings, a number of objectives were defined for reaching LSTA's goals of learning to read and loving to learn. These include (1) services strengthened by collaboration with agencies in the community; (2) services based on long-range communitybased plans; (3) programs that are attractive to children and teens, making them aware of library services; (4) access to accurate, current, and attractive resources; and (5) access to services that respond to their needs and interests.

In 1999, the Powerful Partners plan was finalized as a means of ensuring that youth and children of North Carolina would be able to benefit from collaborative efforts that promote a love for learning and reading. Grant writers and recipients of Powerful Partners grants must be visionaries, who can serve as leaders for the purpose of combining resources and efforts for the ben efit of youth and children. Indeed, the use of effective strategies for successful collaboration is a qualifying characteristic for grant recipients. Stated within the grant's guidel ines are clear directives for identifying community needs and providing services to meet those needs by forming strong, well-devel oped partnerships. The creative energy resulting from these collaborations provides young people opportunities to experience a variety of resources, talents, and perspectives. In addition, community-based projects bring diverse perspectives 
that can strengthen the quality of the collections in school libraries, and attract school children to the public library.

\section{What Does a Powerful Partner Look Like?}

Granville County. When two creative minds come together, the collaboration can sometimes be even better than either originally envisioned. Such is the case with a Powerful Partners grant co-written by Dasie Roberts and Markie Duckworth. They had been discussing for some time their shared vision to bring authors and illustrators to visit their libraries, but lacked the funds to turn the vision into reality. Their grant for $\$ 56,200(\$ 50,000$ from the State Library and a matching $\$ 6,200$ from local sources such as individual schools, the Kiwanis Club, and the Granville Education Foundation) was written in June 2000. Its title, Books Alive: The Literary Connection, succinctly phrased its purpose: to make books, writing, illustrating, and the literary process come alive for the children of Granville County. A major aspiration was to get as many authors and illustrators as possible in front of as many children as possible. Sixteen authors and illustrators eventually visited both the Granville County Schools and the Richard Thornton Library. And quite an eclectic guest list it was. Placing a concerted effort on promoting multiculturalism, the program attracted authors as diverse as Christopher Paul Curtis, Kimberly Johnson, Cowboy Jim Gregory, and Pat Mora, and illustrators as different as Michael White and Javaka Steptoe, who shared their work and work ethic with the children of Granville County.

Durham County. Teens recruited through area school media centers delivered storytime programs to nearly 3,000 el ementary students at the Durham County Public Library. In addition, they teamed up with the Durham Public Library's bookmobile to present stories at daycare centers and local library branches. What made this partnership especially unique was the development of an original children's story. Over a time period of eight years, a total of twenty-four students will be trained for these highly coveted, paid positions as storytime developers and presenters. Also in Durham, Youth ALIVE! provides opportunities for local youth to train as guides, presenters, animal keepers, classroom assistants, exhibit researchers, and designers for the Museum of Life and Science.

Wake County. Wake County Public Schools, Boys and Girls Clubs, and Wake County Public Libraries worked together to prepare youth in the community to become better users of technology for practical research and information organization skills. Powerful Partner grant funds were used to purchase computers and software that could be used for "Teens Training Teens" projects. North Carolina requires students to pass a computer skills test before being promoted from the eighth grade. For this project, technologically fluent teens were selected and trained to serve as tutors to help other teens gain skills in computer and information literacy.

Perquimans County. Pettigrew Regional Library, Perquimans County Library, and area schools worked together to create a community of readers. According to Jeri Oltman and Melissa Fields, "it all came about through our conversations ... everything we could do for parents to have activities that promote a community of readers." Both testified to a strong sense of personal trust as they brainstormed ideas that included Family Reading Nights, storytellers, book fairs, Read Across America, and even parents trying their hands at Accelerated Reader ${ }^{\circledR}$ tests. Both held the same values for a shared vision for promoting readers among families in this rural community in eastern North Carolina.

There are other success stories that support the value of community partnerships among libraries, schools, and other agencies. A description of Powerful Partner Grants for years 2000 to 2002 is provided in Table 1. ${ }^{4}$ 
Table 1. State Library of North Carolina Powerful Partners Grant recipients and their partners over a two-year period, 2000/2001 - 2001/2002. Surveys were mailed to a participant for each project.

\begin{tabular}{|c|c|c|}
\hline Name of Project & $\begin{array}{l}\text { Amount } \\
\text { of Funds }\end{array}$ & Partners \\
\hline $\begin{array}{l}\text { Low Income Family } \\
\text { Literacy Project }\end{array}$ & $\$ 55,000$ & $\begin{array}{l}\text { Asheville-Buncombe Library System and the } \\
\text { Buncombe County Health Department }\end{array}$ \\
\hline $\begin{array}{l}\text { West Asheville } \\
\text { Hispanic Community } \\
\text { Outreach Project }\end{array}$ & $\$ 55,000$ & $\begin{array}{l}\text { Asheville-Buncombe Library System, the Migrant Education } \\
\text { Program of the Buncombe County Schools, Western North } \\
\text { Carolina Community Health Services, Catholic Social } \\
\text { Services, and others }\end{array}$ \\
\hline $\begin{array}{l}\text { A Community } \\
\text { Celebration of History }\end{array}$ & $\$ 5,500$ & $\begin{array}{l}\text { Sherrills Ford Branch of Catawba County Library System, } \\
\text { Sherrills Ford Elementary School, and the Catawba County } \\
\text { Community School Program }\end{array}$ \\
\hline $\begin{array}{l}\text { Library Youth } \\
\text { Partnership Project }\end{array}$ & $\$ 31,484$ & $\begin{array}{l}\text { The Durham County Library, the NC Museum of Life and } \\
\text { Science, and Hillside and Southern High Schools. Includes } \\
550 \text { elementary school children and } 12 \text { high school students. }\end{array}$ \\
\hline $\begin{array}{l}\text { Minority and At-risk } \\
\text { Youth Writing and } \\
\text { Photography Project }\end{array}$ & $\$ 30,616$ & $\begin{array}{l}\text { Forsyth County Public Library, County Hispanic Services, } \\
\text { the Winston-Salem Journal and Que Pasa newspapers, and the } \\
\text { Sawtooth Center for Visual Art }\end{array}$ \\
\hline $\begin{array}{l}\text { Write Between the } \\
\text { Lines }\end{array}$ & $\$ 47,695$ & $\begin{array}{l}\text { Haywood County Public Library, Haywood County } \\
\text { Community College, Haywood County Public Schools, and } \\
\text { Smoky Mountain News }\end{array}$ \\
\hline $\begin{array}{l}\text { The Village } \\
\text { Storytelling Festival }\end{array}$ & $\$ 11,269$ & $\begin{array}{l}\text { Public Library of Charlotte and Mecklenburg County, } \\
\text { University City Regional Library, Nathaniel Alexander and } \\
\text { Morehead Elementary Schools }\end{array}$ \\
\hline $\begin{array}{l}\text { Family Computer/ } \\
\text { Internet Workshops }\end{array}$ & $\$ 5,500$ & Cherokee County Library and the Cherokee County Schools \\
\hline $\begin{array}{l}\text { A Community of } \\
\text { Readers }\end{array}$ & $\$ 40,150$ & $\begin{array}{l}\text { Pettigrew Regional Library, Perquimans County Public } \\
\text { Library, Perquimans County Public School System, County } \\
\text { Chamber of Commerce, Communities in Schools, } \\
\text { and the Childcare Resource and Referral Programs }\end{array}$ \\
\hline $\begin{array}{l}\text { The Literary } \\
\text { Connection }\end{array}$ & $\$ 56,200$ & $\begin{array}{l}\text { Granville County Public Library, West Oxford Elementary School, } \\
\text { Butner-Stem Middle School, and Granville Education Foundation }\end{array}$ \\
\hline $\begin{array}{l}\text { Middle Mix-ups Book } \\
\text { Discussion Groups }\end{array}$ & $\$ 16,720$ & $\begin{array}{l}\text { Watauga County Library, Watauga County Schools, Appalachian } \\
\text { State University, and the Watauga Education Foundation }\end{array}$ \\
\hline $\begin{array}{l}\text { Hispanic Literacy } \\
\text { Outreach Program }\end{array}$ & $\$ 13,970$ & $\begin{array}{l}\text { Wake County Public Library, Zebulon Elementary, Eastern } \\
\text { Regional Human Services Center, and St. Eugene Catholic Church }\end{array}$ \\
\hline $\begin{array}{l}\text { PAIRS (Partners in } \\
\text { Reading) }\end{array}$ & $\$ 26,345$ & $\begin{array}{l}\text { Cumberland Public Library and Information Center, Cross } \\
\text { Creed Reading County, and tutors provided by local schools' Beta } \\
\text { Clubs and National Honor Societies }\end{array}$ \\
\hline Project InterAct & $\$ 14,386$ & $\begin{array}{l}\text { Public Library of Charlotte and Mecklenburg County, Children's } \\
\text { Theatre of Charlotte, and at-risk children from area schools }\end{array}$ \\
\hline $\begin{array}{l}\text { Life Skills through } \\
\text { Cooperative Extension } \\
\text { Programs }\end{array}$ & $\$ 46,000$ & $\begin{array}{l}\text { Northwestern Regional Library (includes } 4 \text { counties), } \\
\text { community colleges, and Cooperative Extension Programs }\end{array}$ \\
\hline $\begin{array}{l}\text { Our Own Back Yard a } \\
\text { Very Good Place to } \\
\text { Start }\end{array}$ & $\$ 50,000$ & $\begin{array}{l}\text { Rockingham County Public Library System, Rockingham } \\
\text { County Schools, School Media and Technology Center, and } \\
\text { multiple community agencies }\end{array}$ \\
\hline $\begin{array}{l}\text { Mastery of Computer } \\
\text { Competencies for 8th } \\
\text { Graders }\end{array}$ & $\$ 49,678$ & $\begin{array}{l}\text { Wake County Public Libraries, Boys and Girls Clubs, and East } \\
\text { Wake Middle School }\end{array}$ \\
\hline Web of Support & $\$ 30,509$ & $\begin{array}{l}\text { Wiley International Elementary Magnet School, Pullen Memorial } \\
\text { Baptist Church, and Wake Technical Community College }\end{array}$ \\
\hline
\end{tabular}




\section{Research Questions and Method for Gathering Data}

State Library Federal Programs Consultant Penny Hornsby serves as the contact person for the Powerful Partners Collaboration Grants. In an interview, she reported that the operative word for Powerful Partners is collaboration. To be competitive for the grant, the applicant must describe a project that includes elements of a successful collaboration. Guidelines for the partnerships include recommendations from the Amherst $\mathrm{H}$. Wilder Foundation. The Wilder Foundation is a nonprofit health and human services organization that supports research and evaluation to strengthen individuals, families, and communities. ${ }^{5}$ As a result of its ongoing research, the Wilder Foundation provides basic elements needed for achieving successful collaborative projects. These are categorized as image; mutual trust; sustained enthusiasm; shared vision, goals, and objectives; accountability; flexibility; and communication. Within these eight categories, the Wilder Foundation has identified twenty factors that influence successful collaboration and provided criteria for establishing the partnerships. Using these twenty factors, an inventory (in survey format) was developed for the purpose of gathering information on Powerful Partners grant recipients. Responses from the surveys were tallied, and scores calculated by figuring the average for each response to items in the inventory. The Wilder Foundation recommends the following values for scores: 4.0 - 5.0, strong likelihood for success; 3.0 - 3.9, borderline performance, needs to be discussed by the team; 2.9 or lower, not likely to have success in the project, revisions in group processes needed. 6

For this study, there were three questions. First, have Powerful Partner grant recipients been satisfied with partner organizations and is there a perception that outcomes were positive? Second, what factors can be identified as predominant within the partnership, and, third, are there correlations between scores from the case study provided by the Wilder Foundation and scores from a survey sent to North Carolina librarians and their partners? Both quantitative data from surveys and qualitative data from telephone interviews were used to draw conclusions related to these questions. A fortyeight-item survey was developed to measure perceived satisfaction and effectiveness for the partnership. The survey items replicated the content suggested by the twenty factors for successful collaboration recommended by the Wilder Foundation. Three of the survey items were designed to gather demographic information on the survey participants, including geographic location, economic conditions, and level of illiteracy of the community. Participants in the survey were instructed to respond to each item by selecting 1,2 , 3,4 , or 5 on a Likert Scale, where $1=$ strongly disagree, and $5=$ strongly agree.

Using contact information available from the State Library of North Carolina, surveys were mailed to Powerful Partners grant recipients. These included public library personnel and school librarians, who had partnered with the public libraries. Of the twenty-two surveys mailed, thirteen responded. Two of the responses were from school librarians. The remaining eleven were from public librarians. The results were tallied and calculated to determine the average score for each item as in the Wilder Foundation's case study.

\section{Results}

Participants were from all areas of the state, including rural and urban areas of the mountains, coastal plain, and piedmont regions. Communities were diverse with industry, farming, tourism, retail/commercial businesses, and research/education as the predominant categories of employment. Illiteracy was a concern for many of those responding to the survey, but it was not as serious as predicted.

In addition to recommendations for successful partnerships, the Wilder Foundation has also provided information from case studies that can be used 
as baseline data needed for identifying collaborative projects that are likely to be successful. ${ }^{7}$ This data was used to make comparisons between Wilder Foundation case study projects and Powerful Partners projects in North Carolina. Although the number of participants from North Carolina was small, those responding clearly showed positive perceptions of their projects, one of the factors associated with successful collaborations. As can be seen in Table 2, scores for North Carolina Powerful Partners are closely aligned with scores supplied by the Wilder Foundation case studies. A close examination of scores for each of the individual factors shows four factors in which Powerful Partners projects and the Wilder Foundation projects differ.

Table 2. Comparison of factors affecting collaboration between NC Powerful Partners and case study provided by Wilder Foundation.

\begin{tabular}{|c|c|c|}
\hline $\begin{array}{l}\text { Factors Affecting Success in Collaboration } \\
1=\text { highly disagree, } 5=\text { highly agree }\end{array}$ & $\begin{array}{c}\text { Average Scores } \\
\text { Powerful } \\
\text { Partners of NC } \\
\mathrm{N}=13 \\
\end{array}$ & $\begin{array}{c}\text { Average Scores } \\
\text { Wilder } \\
\text { Foundation } \\
\mathrm{N}=18 \\
\end{array}$ \\
\hline History of collaboration or cooperation in community $\left[\mathrm{V}^{*}, \mathrm{~T}^{*}\right]$ & 3.75 & 4.2 \\
\hline Group seen as legitimate leader in the community $\left[\mathrm{V}, \mathrm{T}, \mathrm{G}^{*}\right]$ & 4.15 & 4.4 \\
\hline Favorable political and social climate [V] & 4.4 & 4.5 \\
\hline Mutual respect, understanding and trust $[\mathrm{T}]$ & 4.8 & 3.3 \\
\hline Appropriate cross section of members $[\mathrm{V}, \mathrm{G}]$ & 4.2 & 4.4 \\
\hline Members see collaboration as in their self-interest $[\mathrm{V}, \mathrm{G}]$ & 4.8 & 4.5 \\
\hline Ability to compromise [G] & 4.1 & 4.3 \\
\hline Members share a stake in both process and outcome $[\mathrm{V}, \mathrm{T}]$ & 4.3 & 4.4 \\
\hline Multiple layers of participation [V, G] & 4.1 & 4.6 \\
\hline Flexibility $[\mathrm{T}]$ & 4.4 & 4.4 \\
\hline Development of clear goals and policy guidelines [G] & 4.1 & 4.1 \\
\hline Adaptability [T] & 4.2 & 4.6 \\
\hline Appropriate pace of development [G] & 3.75 & 4.3 \\
\hline Open and frequent communication $[\mathrm{T}]$ & 4.3 & 4.4 \\
\hline Established formal and informal relationships [T] & 4.5 & 2.4 \\
\hline Concrete attainable goals and objectives [G] & 4.5 & 4.2 \\
\hline Shared Vision [V] & 4.35 & 4.4 \\
\hline Unique purpose $[\mathrm{V}, \mathrm{G}]$ & 4.15 & 4 \\
\hline Sufficient funds, staff, materials, and time [G] & 3.9 & 4.5 \\
\hline Skilled leadership [T] & 4.5 & 4.4 \\
\hline Average scores for $\mathbf{2 0}$ factors & 4.265 & 4.215 \\
\hline
\end{tabular}

* Survey item includes elements of the following:

$\mathrm{V}=$ shared vision, $\mathrm{T}=$ mutual trust, $\mathrm{G}=$ distinctive goals

Note in Table 2 the survey item related to "mutual trust and respect." Powerful Partners scored an average response of 4.8 on the Likert scale, whereas the Wilder Foundation reported a much lower average response of 3.3 from participants in their case studies. A second factor of interest is related to "establishing formal and informal relationships." Powerful Partners scored a high 4.5 average response for the survey item related to "establishing formal and informal relationships." The Wilder Foundation reported a much lower average response (2.4) for this same survey item. Other differences included self-reported satisfaction with "adaptability of team members to make needed 
changes" and "availability of resources (human services) to achieve goals for the project."

Telephone interviews were used to gather additional information beyond the quantitative data provided in items on the survey. Open-ended questions were designed to determine the occurrence of three main themes for each

Table 3. Factors Affecting Collaboration for Powerful Partners in North Carolina

\begin{tabular}{|c|c|c|}
\hline Factors & Description & $\begin{array}{l}\text { Average } \\
\text { Response }\end{array}$ \\
\hline Mutual Trust & $\begin{array}{l}\text { Characteristics of group members are important. An assessment of } \\
\text { individual skills, attitudes, and cultural norms and values would provide } \\
\text { information needed for developing mutual trust and respect. The } \\
\text { collaboration should include someone from each segment of the } \\
\text { community, who would be affected by the project activities. }\end{array}$ & 4.8 \\
\hline $\begin{array}{l}\text { Formal and } \\
\text { Informal } \\
\text { Relationships }\end{array}$ & $\begin{array}{l}\text { There are times and circumstances that are appropriate for each } \\
\text { exchange of information. In the beginning, formal letters are } \\
\text { important. Later, informal contact by telephone or personal } \\
\text { meetings may be needed to sustain motivation and interest. }\end{array}$ & 4.5 \\
\hline $\begin{array}{l}\text { Concrete, } \\
\text { Attainable Goals }\end{array}$ & $\begin{array}{l}\text { Goals and objectives must be purpose-driven, based on needs, } \\
\text { crises, or opportunities discovered in the community. They } \\
\text { must be set high enough to maintain motivation and interest, yet } \\
\text { realistic and obtainable to prevent abandonment. }\end{array}$ & 4.5 \\
\hline $\begin{array}{l}\text { Open and Frequent } \\
\text { Communication }\end{array}$ & $\begin{array}{l}\text { Communication must be open, clear, and appropriate to meet the } \\
\text { needs of a diverse group. }\end{array}$ & 4.3 \\
\hline Shared Vision & $\begin{array}{l}\text { Reaching consensus is important since it would be impossible for } \\
\text { the group to agree about every issue throughout the life of the } \\
\text { project. The unique and distinctive vision for a project can be } \\
\text { determined in advance, or born out of dialogue occurring during } \\
\text { early planning meetings. }\end{array}$ & 4.3 \\
\hline $\begin{array}{l}\text { Appropriate } \\
\text { Cross Section } \\
\text { of Members }\end{array}$ & $\begin{array}{l}\text { Be sure to include talented, key people from each layer of the } \\
\text { organization or agency. }\end{array}$ & 4.2 \\
\hline $\begin{array}{l}\text { Image as } \\
\text { legitimate } \\
\text { leaders in the } \\
\text { community }\end{array}$ & $\begin{array}{l}\text { The group should project an image within the community that } \\
\text { suggests reliability and competence. An initial assessment of } \\
\text { group members' reputations in the community may reveal areas } \\
\text { of deficiency. Assessment of image within the community should } \\
\text { be on-going throughout the life of the collaboration. }\end{array}$ & 4.15 \\
\hline Unique Purpose & $\begin{array}{l}\text { The purpose for the project must be distinct from any goal or } \\
\text { purpose already named by individual agencies or organizations. } \\
\text { This serves two purposes: (1) sustained interest, and ( } 2 \text { ) avoidance } \\
\text { of "turf issues" related to individual goals or objectives. }\end{array}$ & 4.15 \\
\hline $\begin{array}{l}\text { Ability to } \\
\text { Compromise }\end{array}$ & $\begin{array}{l}\text { Flexibility in problem solving is essential to overcome } \\
\text { unexpected delays and stumbling blocks. In addition, roles, } \\
\text { rights, and responsibilities for each group member should be } \\
\text { clearly communicated. Begin with a firm set of guidelines, } \\
\text { gradually moving to more flexibility as group members will } \\
\text { eventually gravitate to their preferred roles and objectives. }\end{array}$ & 4.1 \\
\hline $\begin{array}{l}\text { Sufficient funds, } \\
\text { staff, materials, } \\
\text { and time }\end{array}$ & $\begin{array}{l}\text { Over time, it may become necessary to change group members. } \\
\text { As goals are matched to available resources, disbursements of } \\
\text { resources and funding may change. }\end{array}$ & 3.9 \\
\hline $\begin{array}{l}\text { History of } \\
\text { Collaboration }\end{array}$ & $\begin{array}{l}\text { Consideration should be given to collaborative projects in the } \\
\text { past and how these have affected the social, political, and } \\
\text { environmental factors within a community. }\end{array}$ & 3.75 \\
\hline $\begin{array}{l}\text { Appropriate } \\
\text { Pace }\end{array}$ & $\begin{array}{l}\text { Plans should be implemented to ensure a progression of smaller } \\
\text { successes so that major goals are realized. }\end{array}$ & 3.75 \\
\hline
\end{tabular}


partnership. These were "shared vision," "mutual trust and respect," and "distinctive and unique objectives" for the project. Interviewees were selected from survey respondents with consistently high scores or those who had highly variable scores. In the final analysis, six individuals were interviewed by telephone or in a face-to-face taped interview. Table 3 provides the predominant themes that emerged from telephone interviews. In Col-

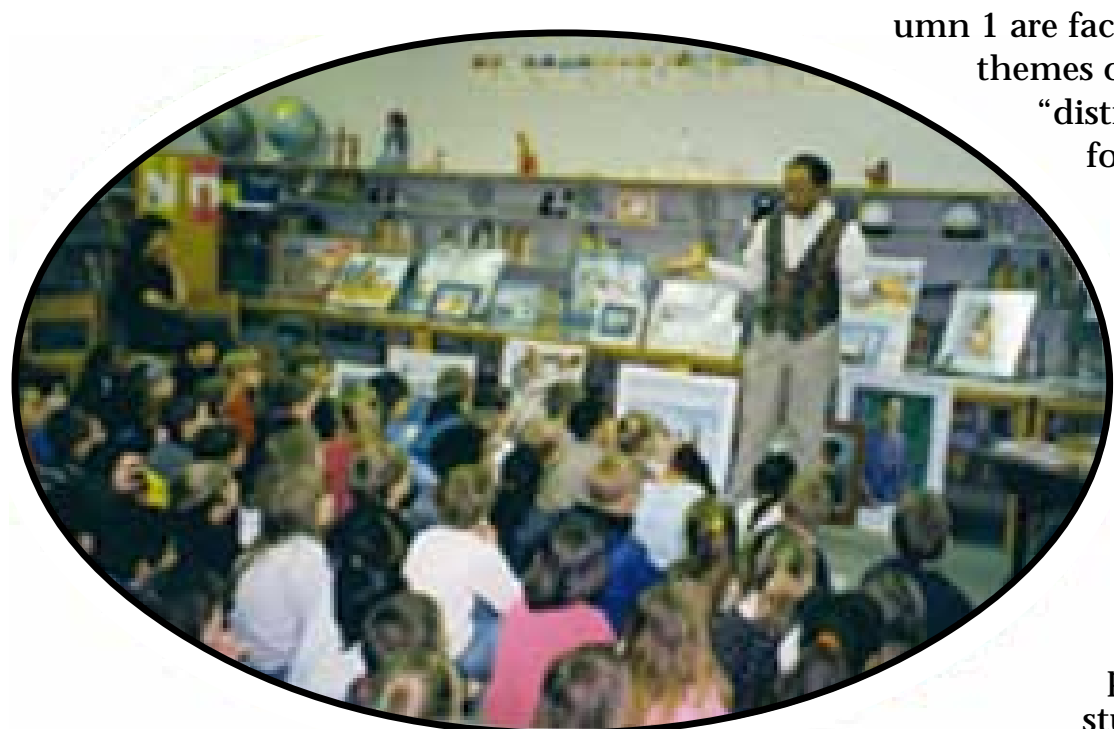

of "shared vision," "mutual trust," and "distinctive goals and objectives." ${ }^{8}$ Descriptions for each factor are provided in Column 2. The corresponding scores from surveys mailed to Powerful Partner participants are in Column 3.

Note that survey factors related to the major themes of mutual trust, shared vision, and distinctive objectives have the highest average scores as reported by respondents to the survey. North Carolina Powerful Partners scored a high average for all factors, slightly higher than the average for the eighteen projects used in the Wilder Foundation case Illustrator James Melvin brought delightful art samples and techniques for Powerful Partners in Granville County. For more information on Melvin's work see $<$ http://www.suzannetate.com/authorillus.htm>. (Photo provided by Robin Boltz, Library Media Coordinator, Granville County Schools.)

studies ( $\mathrm{NC}=4.26$, Wilder cases $=4.21$ ). One other difference is noteworthy. For the factor,

"history of collaboration within the region,"

Powerful Partners had an average score of 3.75, whereas the Wilder Foundation was 4.2 (see Table 1).

\section{Elements of Shared Vision}

Clearly, a shared vision is a common and reoccurring theme for all the partnerships interviewed. Each of the participants stated that the partnership "came together" because they wanted to serve the youth and children in the community through books, technology, or other information resources. For those who started with a conceptual idea for an al ready existing project, initial meetings consisted of brainstorming sessions to talk about problems and issues in the community. Dialogue in these meetings was for the identification of problems and for generating possible solutions. Those participating in the first few meetings made recommendations for additional partners who might be suitable for the project. For others, the project goals and objectives had been defined earlier in the grant process. Their first meetings were more focused on timelines, sharing of resources, and strategies for implementation of the project goals. Whether or not project goals were al ready established, their visions were completed through the interagency collaboration process. The following comments from a rural coastal community, with high illiteracy, support the idea that a shared vision is critically important to the success of the projects.

Whatever little problems that we might have encountered did not interfere with our goal for getting books and resources into the hands of these children.... Shared vision was the result of a need in our community.

Another project resulted from economic needs within a rural mountain community.

We wanted to provide information and support for preparation, training, and specialized education for good jobs. It was gratifying to see this shared vision. There was a process for generating this shared vision. We met regularly to determine our goals and a common vision. We had to 
build relationships to do this and it took time. All those on the planning team formulated the vision statement....

The following statements reflect a situation in which a shared vision evolved from open communication and trust. These comments are from a respondent in an urban setting located near a research-based, academic community.

Our shared vision began as a result of our conversations. We started by inviting potential partners. By starting from no preconceived idea of our goal and by developing goals together, we were easily able to develop a shared vision. We brainstormed and looked at the needs for the community. Actually, the best part of the collaborative experience was during the initial meetings.

Note in Table 1, high scores for both "shared vision" and "open communication" were reported by a large number of survey respondents.

\section{Elements of Mutual Trust}

The interviews contained many comments focused on conditions leading to personal feelings of trust. For one participant, failed trust was a factor leading to some disappointment.

We started well, then lost trust in the end. We met regularly but some members didn't reveal that they were experiencing failure and that they were struggling. Thus, at the end, we lost the trust that we had experienced in the beginning.

Most of the participants reported a positive experience for mutual trust and respect. Further study on the values and norms for this geographic region, compared to other regions in the country, may reveal a difference in levels of trust and respect. For example, did the grant participants enjoy camaraderie simply because of the success of the partnership or did camaraderie produce a sense of trust? What about similar values and norms? Could these be stronger factors than positive personal relationships?

I think our shared vision built trust ... another thing that built trust was the type of relationship we enjoyed ... we developed a mentor-mentee relationship. This was meaningful for both of us and contributed to our trusting relationship.

\section{Elements of Distinctive Goals}

Collaboration requires the commitment of organizations and their leaders. "Two or more organizations are not just mushed together," but instead, a new common mission and goals are created. ${ }^{9}$ Many of the studies of successful collaboration consistently identify a unique goal or set of objectives for the project. These should be separate and distinctively different from goals and objectives already identified by contributing agencies, organizations, or individuals. ${ }^{10}$ Each agency will have specific resources that are available for the community. Because of administrative and bureaucratic policies, these re sources are often carefully guarded by the contributing agency. The desire for personal recognition can hinder the blending of resources to achieve a distinctive goal for the project. Some of the participants for this study reported problems with ownership of goals and needed a "coming together" to generate a distinctive goal statement for the project.

We had to build relationships to do this and it took time. I think you can't rely on just one key relationship but reach out to several who may contribute to the collaboration. There is some frustration in building these relationships.

Others reported a more favorable experience when determining distinctive goals for the project.

Our goals were related to computer literacy, but the unique and distinctive goal for the partnership was to experience successful collaboration. 
So, while the youth were learning research skills on the computer, team members learned about strategies for successful collaboration.

\section{Time}

In two of the interviews, the Powerful Partners reported concerns with lack of time for scheduled meetings, planning, and meeting deadlines for the project. We as sponsors had to deal with illness, job transfers, and scheduling conflicts with facilities, but we still were able to pull it off and very successfully! ...The only negative aspect was that there never seemed to be enough time. It was often difficult for people of different organizations and different schedules to coordinate meetings, activities, etc. ... we however made the best of the time together.

\section{Conclusions}

Powerful Partners grant recipients from North Carolina libraries have demonstrated positive outcomes for projects that required interagency collaboration to meet an identified need within the community. Although the sample size was small, interviews and survey responses came from urban, rural, and suburban populations, representing a diverse cross section of North Carolina. Average scores from self-reported survey data indicated that grant participants had adopted recommendations for successful collaboration as reported in the literature. There was also willingness among several of the participants to offer candid remarks on changes needed for improvement in future projects.

Survey respondents with high scores for all items and respondents with varying scores were interviewed by telephone. Those with low scores in the item "formal and informal communication," and for the item related to "adequate human resources," reported through interviews that lack of time and/or motivation by partners seemed to reduce effectiveness of the partnership. Partners may not have been able to schedule time for planning, thus commitments for resources and other contributions were lacking. Lack of time and strategies for time management were obstacles.

A second concern was related to open communication and follow-up with all the stakeholders involved. Comments related to open communication indicated a lack of time by one or more partners within the collaboration. Lack of sustained motivation was also mentioned which would suggest that partners, who were fully and consistently informed for all facets of the projects, were more likely to maintain enthusiasm and commitment. Mattessich emphasizes the importance of ongoing visibility of goals throughout the life of the project. ${ }^{11}$ Informal communication that reminds partners of mutually beneficial goals could provide the incentive needed for partners to remain committed even when obstacles related to time and dwindling resources occur. Another important factor is related to type of communication. ${ }^{12}$ Impersonal correspondence or other forms of written communication may not have the effect needed to gain attention from a partner, who faces new and more pressing priorities. When partners lose interest, personal contact through tel ephone or visits may revitalize interest.

There were others, who reported a very high level of satisfaction, because, even with obstacles such as lack of time to meet and plan, goals were achieved. There were those, participating in the interviews, who exhibited a synergy that is hard to define and quantify. One partnership resulted in a mentor-mentee relationship. The principle grant writer provided valuable guidance and mentoring for the younger, less-experienced partner. One explanation for this kind of outcome could be related to initial brainstorming sessions in which all partners worked together to generate the shared vision statement. Natural leaders would emerge and those with unique and specific skills could be identified for the good of the project. Another constant theme that seemed to contribute to synergy among partners was the mutually al truistic desire to achieve goals for the good of their community. Comments from those participating in the 
interviews consistently reported that commitment to the project's goals was stronger than barriers caused by lack of time.

The Wilder Foundation's twenty factors for successful collaboration can be aligned with the three commonly occurring themes: (1) shared vision, (2) mutual trust/respect, and (3) unique/distinctive goal statements. These clearly emerged during an analysis of the interviews. Organizations and agencies may find it useful to begin planning with these three themes in mind, followed by implementation of more specific (and measurable) strategies based on the twenty-factor inventory.

Although participants were able to identify and report problems that caused some dissatisfaction with the partnerships, those responding to the interviews voiced a desire to participate in future or continuing partnerships with others in their community. Clearly, the personal satisfaction experienced by realizing their visions and achieving goals for services to children and youth in their communities was a dominant theme.

\section{References}

1 Institute of Museum and Library Services, "Grants to State Library Agencies," «ttp://www.imls.gov/grants/library/lib_gsla.asp\#vitals> (accessed June 24, 2003).

2 State Library of North Carolina, "LSTA Powerful Partners Collaboration Grants," «ttp://statelibrary.dcr.state.nc.us/Ista/PP_GL_03-04.pdf> (accessed May 15, 2003).

3 State Library of North Carolina, "Evaluation of the Library Services and Technology Act Plan for Implementation in North Carolina," «ttp://

statelibrary.dcr.state.nc.us/Ista/LSTAEvalReport1101.pdf> (accessed J une 24, 2003).

4 State Library of North Carolina, "LSTA, Library Services and Technology Act: Previous Awards," «tttp://statelibrary.dcr.state.nc.us//sta/PrevAwards.htm> (accessed June 18, 2003).

5 Paul W. Mattessich, and Barbara R. Monsey, Collaboration: What Makes it Work: A Review of Research Literature on Factors Influencing Successful Collaboration (St. Paul, M N: Amherst H. Wilder Foundation, 1992), 47.

6 Wilder Foundation. "Wilder Foundation Factors Inventory," «ttp:// www.wilder.org/pubs/inventory/CollaborationA.html > (accessed May 15, 2003).

7 Paul W. Mattessich, Marta Murray-Close, Barbara R. Monsey, and Wilder Research Center, Collaboration: What Makes It Work, 2nd ed. (St. Paul, MN: Amherst H. Wilder Foundation, 2001), 26.

8 Ibid., 12.

9 Lizabeth A. Wilson, "Collaborate or Die: Designing Library Space," Association for Research Libraries: A Bimonthly Newsletter of Research Library Issues and Actions from ARL, CNI, and SPARC (June, 2002), ‘tttp://www.arl.org/newsltr/222/> (accessed May 15, 2003).

10 Hal A. Lawson, and Wayne Sailor, "Integrating Services, Collaborating, and Developing Connections With Schools," Focus on Exceptional Children 33 (Oct. 2000): 1-22; Charles Bruner. "Thinking Collaboratively: Ten Questions and Answers to Help Policy Makers Improve Children's Services" (ERIC document: ED 338 984, 1991).

11 Mattessich et al., 17.

12 Ibid., 24.

\section{Bibliography}

If you would like additional information on the Powerful Partners Grant Projects, visit the following Web sites.

Institute of Museum and Library Services. "Collaboration Highlight for 2002: Youth Alive." <http://www.herald-sun.com/ncmls/news/news.html >Accessed June 24, 2003.

Burton, Mel. “Chapbook, Vol. 28." <http://www.imls.gov/closer/archive/ hlt c0102.htm>Accessed June 24, 2003.

Robin Boltz, and Carol A. Brown. "Powerful Partners" [unpublished manuscript]. $<$ «ttp://www.coe.ecu.edu/LTDI/brown/PowerfulPartners. htm>Accessed June 24, 2003. 